\title{
Megaloblastic anaemia in non secretory multiple myeloma: a rare presentation
}

\author{
W D D Priyankara ${ }^{1}$, D Gunawardena ${ }^{2}$
}

Ceylon Medical Journal 2013; 58: 89-90

\section{Introduction}

Multiple myeloma is a plasma cell neoplasm characterised by clonal proliferation of plasma cells in the bone marrow, presence of monoclonal protein or light chains in blood or urine and related organ dysfunction. It is commoner among men than women with a median age of onset of 70 years. We report a case of non secretory multiple myeloma (NSMM) presenting as megaloblastic anaemia (MA).

\section{Case report}

A 31-year old army soldier presented with a four day history of fever and malaise. He was a teetotaller and a non-vegetarian. Physical examination was unremarkable There was no lymphadenopathy or organomegaly. Fever subsided spontaneously. Investigations showed pancytopaenia (WBC $2.2 \times 10^{3} / \mu 1, \mathrm{~L}: 65 \%$, N:19\%, platelets $77 \times 10^{3} / \mu \mathrm{l}$, haemoglobin $10.5 \mathrm{~g} / \mathrm{dl}$ ). MCV was $106.5 \mathrm{fl}$. Blood picture was typical of megaloblastic anaemia with oval macrocytes and hypersegmented neutrophils. ESR was $58 \mathrm{~mm} / \mathrm{hr}$.

Both serum $B_{12}$ and serum folate levels were low confirming the diagnosis of vitamin $\mathrm{B}_{12}$ and folic acid deficiency. Bone marrow aspiration and trephine biopsy revealed megaloblastic changes. In addition, a plasma cell proliferation of $12-15 \%$ was noted. Despite plasmacytosis in the marrow, repeated serum protein electrophoresis failed to reveal a monoclonal band or immune paresis. The skeletal survey was unremarkable. Patient was started on intramuscular vitamin $\mathrm{B}_{12}$ and folic acid. He had a reasonable response to vitamin supple-mentation with improvement of the anaemia and thrombocytopaenia. However the neutropaenia progres-sively worsened. Three months later, patient presented with acute severe backache. Haematological parameters at this stage revealed a further reduction in his neutrophil count $\left(0.2 \times 10^{3} / \mu \mathrm{l}\right)$ and a mild thrombocytopaenia $\left(115 \times 10^{3} / \mu 1\right)$. MRI spine revealed a wedge compression fracture of third thoracic vertebra accounting for the symptoms. Serum calcium was normal. He was re-investigated for a possible plasma cell dyscrasia. The repeat bone marrow revealed a significant plasma cell infiltrate of $33 \%$ with erythroid dysplasia. Repeatedly negative serum protein electrophoresis prompted us to consider a non secretory plasma cell myeloma. The serum free light chain assay showed an increased $\kappa: \lambda$ ratio of 1.73 (NR: 0.26-1.65). The most conclusive evidence of plasma cell proliferation was found when immuno-histochemistry of bone marrow trephine revealed an $80 \%$ infiltration of neoplastic plasma cells (Figure 1) indicating positivity of CD138 cells with weak/absent expression of $\mathrm{CD}_{45}$ and $\mathrm{CD}_{19}$ (Figure 2). Cytogenetic testing revealed hypodiploidy (35 to 45 chromosomes) of all spreads examined.

The patient was diagnosed with NSMM where the initial presentation was megaloblastic anaemia.

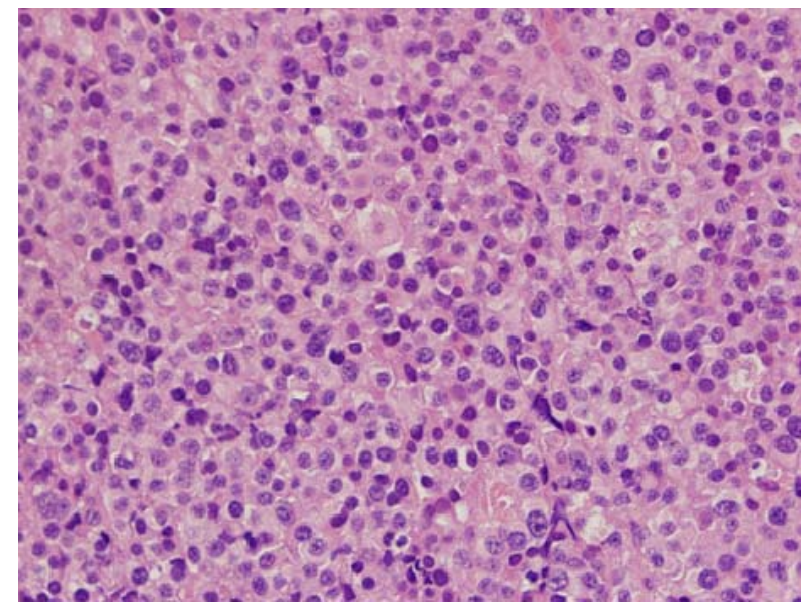

Figure 1. Trephine biopsy - H \& E × $\mathbf{4 0}$ Plasma cell infiltration of the bone marrow.

${ }^{1}$ Colombo South Teaching Hospital, ${ }^{2}$ Department of Pathology, Faculty of Medical Sciences, University of Sri Jayawardenapura, Sri Lanka.

Correspondence: WDDP, e-mail: <dilsh123@gmail.com>. Received 10 May and revised version accepted 11 October 2012. Competing interests: none declared. 


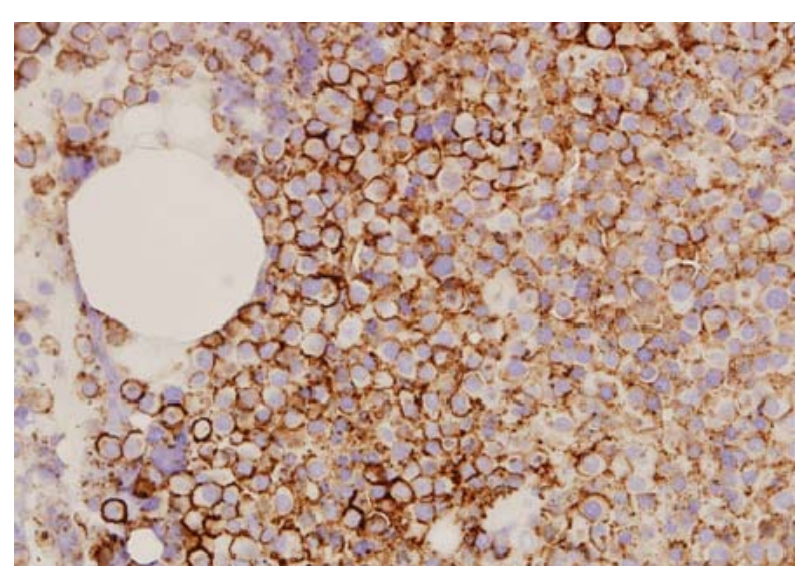

Figure 2. Immuno-histochemistry CD-138 $\times 40$ Most cells stain positive for CD138.

\section{Discussion}

Multiple myeloma is unusual in young individuals such as our patient. Few case reports have described myeloma in patients less than 30 years and a high degree of suspicion is needed to identify these patients [1].

NSMM is a variant of myeloma exhibiting similar clinical features and prognosis in the absence of monoclonal gammopathy. This group constitutes $1-5 \%$ of patients with myeloma. Many chromosomal anomalies have been described in myeloma, but none have been associated with NSMM [2]. Thus the significance of hypodiploidy found in our patient is yet to be determined.

Majority of patients with myeloma have anaemia at presentation and the causes are multifactorial. But MA as the initial presentation is rare. Few reports have described the presence of folic acid deficiency attributed to increased utilisation by the neoplastic cells [3]. $\mathrm{B}_{12}$ levels are normal or elevated in the absence of gastrointestinal disease [3]. Certain studies report an association of myeloma with pernicious anaemia, while some authors suggest that cobalamin uptake and consumption is higher in myeloma cells due to paraprotein synthesis $[4,5]$. Therefore MA can coexist in myeloma.

Treatment with folic acid and cobalamin resulted in an improvement of the anaemia in our patient, but he progressed to overt NSMM within a short period. A similar patient with myeloma progressed from Stage I to stage III of Salmon-Durie staging within 2 weeks of therapy with cobalamin [6]. It is postulated that cobalamin acted as a paracrine growth factor to increase plasma cell growth and osteolytic activity [6].

Therefore MA in myeloma should be treated with caution. Patients with MA and unusual clinical features benefit from regular follow up to identify a possible occult myeloma.

\section{References}

1. Dauth J, De Coning JP, Politzer WM, et al. Unusual presentation of multiple myeloma: A report of 2 cases. South African Medical Journal 1984; 65: 968-71.

2. Heim S, Mitelman F. Chronic lymphoproliferative disorders. In: Cancer Cytogenetics. New York, Wiley-Liss, 2nd Edition 1995: 253-5.

3. Hoffbrand AV, Hobbs JR, Kremenchuzky S, Mollin DL. Incidence and pathogenesis of megaloblastic erythropoiesis in multiple myeloma. Journal of Clinical Pathology 1967; 20: 699-705.

4. Landgren O, Martha S, Linet MS, et al. Familial characteristics of autoimmune and hematologic disorders in 8,406 multiple myeloma patients: A population-based case- control study: International Journal of Cancer 2006; 118: 3095-8.

5. Heyerdahl F, Kildahl-Andersen O. Myelomatosis and low level of vitamin $\mathrm{B}_{12}$. Tidsskr Nor Laegeforen 1999; 119: 4321-2.

6. Schleinitz N, Costello R, Veit V, et al. Rapid evolution of multiple myeloma after cobalamin therapy for megaloblastic erythropoiesis with macrocytic anaemia: Leukaemia Research 1998 ; 22: 287. 